\title{
Post-colonial transitions in Africa: Decolonization in West Africa and present day South Africa
}

\section{Abstract}

Black Economic Empowerment is a highly debated issue in contemporary South Africa. Yet few South Africans realize that they are following a postcolonial trajectory already experienced by other countries. This paper presents a case study of British firms during decolonization in Ghana and Nigeria in the 1950s and 1960s, which saw a parallel development in business and society to that which occurred in South Africa in the 1990s and 2000s. Despite fundamental differences between these states, all have had to empower a majority of black citizens who had previously suffered discrimination on the basis of race. The paper employs concepts from social capital theory to show the process of postcolonial transition in African economies has been more politically and socially disruptive than empowerment in Western countries. Historical research contributes to our understanding of the nature institutional shocks in emerging economies.

Keywords: Institutional transitions, empowerment programs, Africanization, South Africa, Ghana, Nigeria

\section{Introduction}

Business in Africa has struggled with similar challenges as in other emerging economies elsewhere: extremely poor infrastructure (even compared to other developing areas), government involvement in the economy, high transaction costs, opportunism and uncertainty. Yet it is the prevalence of institutional transitions, defined as 'fundamental and comprehensive changes to the formal and informal rules of the game that affect organisations as players' (Peng, 2003, p. 275), that threatens enterprise survival in many emerging economies (Wright et al., 2005). Companies that were strongly embedded in old institutions find that this can become a barrier to successfully managing transitions. This is especially true for African countries that experienced political regime change, and indeed all sub-Saharan African countries that emerged from colonial rule.'

As this paper explores the nature of historical and present-day postcolonial transitions in sub-Saharan Africa, it seeks to address the relative scarcity of contributions on business in emerging economies in this area, which has been noted by Hoskisson et al. (2000) and Wright et al. (2005). Recently, however, Thunderbird International Business Review 
published a special issue on sub-Saharan Africa (2009), and more research on African business history is appearing (Austin \& Uche, 2007; Mager, 2008), which reflects the increasing interest in the region. A comparison between the historical case of two Anglophone West African countries, Ghana and Nigeria, and present day South Africa shows that postcolonial transitions in Africa take similar forms despite significant differences between the countries. Ghana and Nigeria went through an extended phase of postcolonial transition as a result of becoming independent, which was described by contemporaries as the Africanisation of the economy. Between 1950 and 1970, West Africa emerged from many decades of British colonial rule, while South Africa eventually overcame almost half a century of apartheid in the early 1990s. Colonialism and apartheid are similar in that both represent forms of political and economic domination that are based on racial hierarchies which favour white minorities over black majority populations. As a result, there is a great degree of similarity between the postcolonial institutional transitions in West Africa and South Africa, although they occur at different points in time, and deal with somewhat different types of political regimes.

In order to show how companies in West Africa dealt with changes to the rules of game when the new rules were not yet completely clear (Peng, 2003), the cases focus on the HR diversity strategy of large multinational companies from several sectors in the 1950s and 1960s, when environmental pressures to promote more black African managers to responsible positions within firms became significant, yet penalties for non-compliance were not clearly established. This was referred to as the Africanisation of management. In the discussion section, I compare this to present-day South Africa, where Black Economic Empowerment (BEE) is one of the most important government interventions in the economy. BEE seeks to promote a more equitable representation of South Africa's previously disadvantaged ethnic and racial groups in the economy, and especially in the management and ownership of companies listed at the Johannesburg Securities Exchange (JES). For the West African case, corporate archival material and a limited amount of interviews have been conducted, while the discussion section on the implications for the South African case is based on secondary literature and newspaper research. In order to draw out similar dynamics in these two different settings, I employ some concepts from social capital theory to analyse the process of Africanisation in West Africa.

Social capital theory popularized the idea that networks can explain the success of particular individuals and groups, and the exclusion of others from top positions and other economic opportunities, even after open discrimination has ceased. The concept of social capital highlights the importance to economic outcomes of social markers such as background, ethnicity, gender, educational credentials, family background and connections. The work of Granovetter (1992), Alderfer and Smith (1982) on the embeddedness of organisations is relevant here, as is that of Thomas (2001) on mentoring minorities, Waldinger's study (1996) of ethnic groups controlling economic niches in New York, and Pamela Laird's (2006) historical study of the use of networks in American business.

Social capital theory evolved out of the experience of empowerment in Western countries, especially the United States after the Civil Rights movement. However, there are some major differences between empowerment and diversity in Western countries and in Africa. First, in 
Africa the group or groups that had previously suffered discrimination actually constitute the majority population. Second, inter-group dynamics differ fundamentally: empowerment in Africa followed a radical shift in the racial make-up of the ruling group. Hence, companies went from closely mirroring the social and racial realities of white rule to becoming incongruent with their environment once black rule was established. More so than in developed economies, these connections are unstable, and valuable networks can become defunct overnight. There is little research from a social capital perspective of how individuals and organisations deal with a valuable asset like social capital (which is even more indispensable in developing countries) that can become a liability in times of political uncertainty.

\section{Africanization in Ghana and Nigeria}

Ghana and Nigeria are interesting case studies to compare with South Africa because they mark the beginning of decolonization in sub-Saharan Africa. Hence, they were amongst the first African countries to face issues of inter-racial succession in the public and private sectors. Post-apartheid South Africa, in contrast, is among the last states in Africa and the world to undergo the difficult transition from a deeply unequal racial order to a postcolonial state. Moreover, the two West African countries represent two different scenarios of postcolonial social evolution: one where social divisions mostly rest on income and class (Ghana), and one where conflict runs along ethnic lines (Nigeria). In the South African case both patterns occur: class distinctions have become more pronounced in the black population (Terreblanche, 2002, pp. 135-136, 398-400), whereas the relationship among different ethnic or racial groups such as whites (English- and Afrikaans-speaking), coloureds, Asians and blacks is reminiscent of the ethnic divisions in Nigeria (Iheduru, 2004, p. 22). .i This section will deal first with the background to Africanization in West Africa, then review corporate attempts to placate public pressure for greater African participation in management, as well as subsequent programmes to develop reliable and competent African managers to take over firms in an economically difficult and politically radical environment.

\subsection{The Ghanaian and Nigerian Contexts}

Ghana and Nigeria were colonized by the British at the end of the nineteenth century, although coastal colonies existed in both areas from the middle of the century, and trading links in legitimate commodities, as well as slaves, stretched back even further (Hopkins, 1973). For most of the nineteenth century Europeans and African elites collaborated in trade and administration but, by the end of the century, this began to change. As European nations scrambled for African territories, Britain subdued previously independent African kingdoms and less centralized village-based societies, displacing local trading networks with their own firms and transportation infrastructure. Yet, until the early twentieth century, it was still common to see West Africans serving in responsible posts in administration and 
merchant houses (Olusanya, 1975; Coker, 1976). Changing attitudes towards Africans developed out of a combination of advances in medicine, which allowed Europeans to live on the coast without succumbing to malaria and other diseases and a distinct shift in attitudes towards non-Western people in the late nineteenth century, marked by the rise of social Darwinism and racism. Subsequently Africans were effectively barred from highranking positions in the public or private sectors, and isolated attempts from the late 1920s onwards to recruit more West Africans into the civil service faltered (Falola \& Roberts, 1999, pp. 517-520).

After the Second World War the colonial civil service as well as private companies found it difficult to obtain enough white recruits to staff their West African operations, which opened up opportunities for locals again (Nicolson, 1969, p. 261, Decker, 2006, pp. 222-229). Political and economic upheaval in the colonies led their governments to accede to demands for greater self-determination and colonial reform; by the early 1950s this accelerated to become a movement for full-blown decolonization. Ghana became independent under Kwame Nkrumah in 1957, and Nigeria followed suit -- as a federation with three powerful, regionally based political parties -- in 1960 (Falola \& Roberts, 1999; Tignor, 1998, pp. 195292; Gocking, 2007, pp. 75-114). The economic fortunes of both countries, buoyed by the commodities boom of the 1950s, declined in the early 1960s, but then diverged when petroleum reserves were discovered in Eastern Nigeria. While the Ghanian economy declined for most of the 1960s and 1970s, mostly due to government mismanagement and a decline in its traditional exports (cocoa and gold), Nigeria's traditional commodities were displaced by the enormous wealth that oil receipts brought from the late 1960s. In both countries, despite fundamentally different economic environments, political patronage became practically the only way to become wealthy.

Both countries experienced a succession of military coups, interrupted by failing democracies, but their trajectories substantially diverged during the 1980s and 1990s. Ghana successfully implemented one of the first Structural Adjustment Programmes in the 1980s, returned peacefully to democracy in the 1990s, and is now one of Africa's most stable and well-managed countries. However, Nigeria experienced intense inter-ethnic rivalry leading to a civil war from 1967 to 1970 . Resource conflicts continued to define the country's politics, and in the 1980s and 1990s one of Africa's richest and most powerful states declined as a result of ruthless military rulers. The country was returned to a flawed democracy in the late 1990s by the former military governor, Olusegun Obasanjo, who has since been succeeded by Umaru Yar'Adua.

Both Ghana and Nigeria experimented from the late 1960s onwards with legislation to promote indigenization, which forced foreign companies to incorporate locally and to sell equity to local interests. Although these efforts took place in a climate where the overall value of foreign investment was questioned, only a few sectors, such as timber in Ghana and finance in Nigeria, were expropriated completely (Biersteker, 1987, pp. 245-283; Decker, 2006, p. 198). In the 1950s and 1960s the focus was much more on the advancement of local people in the public and private sectors. The former was completely Africanized a few years after independence in both countries but the latter retained a significant expatriate presence until the 1980s which was a source of local irritation. In South Africa the sequence 
was the other way round: Black Economic Empowerment began with equity transfers from white South African companies to black empowerment consortia, while the advancement of black South Africans within companies (originally termed employment equity) gained visibility more slowly.

The West African cases are based on material found in the corporate archives of five firms that were significant in their sectors and the wider economy at the time: the merchant house United Africa Company (UAC), a subsidiary of Unilever, the overseas bank Barclays Bank DCO, and the Ashanti Goldfields Corporation (AGC), a publicly listed gold-mining company operating only in Ghana's Asante region, provide rich and detailed archival resources for this period. Patchier but still informative are two smaller archives, those of the Bank of West Africa and John Holt \& Company, a trading company focusing exclusively on West Africa. All of these companies were British, had a long established presence in both countries, and employed large numbers of locals under mostly expatriate management. These five British companies dominated the private sector until the arrival of the international petroleum firms in Nigeria in the late 1960s and 1970s. Outside the petroleum sector the British firms' major competitors were French, US, and German, but they mostly built a significant presence only in the 1960s. Moreover, in the first few years new foreign investors frequently negotiated better conditions than existing investors, and thus did not become subject to the same pressures until later.

The three largest companies mark the boundaries of how quickly or slowly major firms Africanized their management. UAC embarked on a comprehensive Africanization programme earlier than the other firms, and was followed by the two British banks, Barclays Bank DCO and Bank of West Africa. Progress at AGC was slowest: they formulated a policy only in response to Ghanaian independence (Decker, 2006, pp. 239-273). It is reasonable to assume that other companies occupied the middle ground between UAC and AGC (see Figure 1).ii

\section{INSERT FIGURE 1 ABOUT HERE}

Overall, progress towards Africanization in the private sector was slower than in the civil service. While the latter was under direct political control, the first independent Ghanaian and Nigerian governments only rarely used legal means to coerce foreign companies. Formal conversations between politicians and businessmen, public naming and shaming, and trade union pressure were far more common, but governments also limited immigration quotas for expatriates, even denying new applications completely at times, such as in the early 1960s in Ghana and in the 1970s in Nigeria. Ghana also changed the taxation of expatriate incomes in the early 1960s, which, together with compulsory reinvestment of a share of profits, made the operations of foreign investors very difficult until Nkrumah was deposed in 1966. 


\subsection{External Pressure for Compliance}

When companies first embarked on Africanizing their operations, this was rarely carried through with deep conviction. Rather, it was an attempt to appease external stakeholders, such as the new nationalist parties or the colonial administration, which determined the terms of decolonization. Many high-ranking, prominent appointments were of a political and not a managerial nature. One obstacle was that the directors of Western companies found it difficult to trust their non-European staff. Trust was very low in colonial societies, as Europeans and Africans avoided each other socially and found each others' manners and behaviour unpredictable (Granovetter, 1992, pp. 60-61, 65).

\subsubsection{Promotions and Window-Dressing}

Appointing African directors from outside the companies became a popular, if controversial, practice around the time of independence. The expatriate management hoped that local directors would fulfil similar functions to non-executive directors: providing commercial and political intelligence and access to their network of contacts, while at the same time keeping clear of trying to influence managerial decisions. They effectively sought to gain social capital through local directors, while maintaining publicly that they were prepared to advance Africans within their organization.

In the early 1960s, for example, Barclays Bank DCO made an effort to create local boards to which non-executive African directors were appointed. This occurred first in Nigeria in 1961, shortly after independence, underlining its political motivation. Management was careful to represent all three major ethnic groups (corresponding to the country's administrative regions): Yoruba, Igbo and Hausa. Only one director had a commercial background. While they generally received good publicity for this move, some politicians criticized it as windowdressing (for example Orizu, 1961).

The need for positive publicity made it necessary for the bank to repeat the exercise in Ghana a year later (the country had become independent in 1957 and felt overlooked vis-àvis its larger neighbour). However, the contributions of a retired diplomat and a high ranking civil servant were sparse to non-existent (Barclays, 1960; Boreham, 1961; Wathen, 1961b, not dated). An exception to this was Robert Mensah, one of Barclays' most senior Ghanaian managers, who was appointed to the board on retirement in 1964, and who took an active interest in business affairs. In an interview he commented that the others were little more than 'figureheads' (Stockwell, 2000, p. 145; Wathen, 1964). While Barclays had hoped to use their African directors for political and commercial intelligence, the bank only succeeded in its primary intention - improving its local image -- and that only to an extent. Marshalling the potential of the resources that would arise from linking social networks across the racial divide was not yet possible.

The extent to which some of the early African managers were similarly just 'figureheads', like the non-executive directors, is less clear. The process of promoting and developing capable African managers was fraught with difficulties, and hampered by a hostile environment. In UAC, which had the most rapid Africanization programme of the private sector companies, Africanization at first meant 'adding on' Africans to the existing European managers. There are two different explanations for this: extensive training programmes for 
local staff required more expatriates, or jobs were fragmented by the promotion of expatriates ahead of Africans in order to supervise them.

INSERT TABLE I ABOUT HERE

In both Nigeria and Ghana, UAC's management numbers expanded until 1961 (see Table I), although the company actually centralized operations and sold off smaller trading posts. UAC's expansion took the form of new ventures in manufacturing, increased focus on wholesaling, specialized trading and services, and department stores in major cities. The share of management in the total workforce grew faster: in Ghana from 2.4 per cent in 1949 to 3.2 per cent in 1956, and in Nigeria from 1.7 to 2.6 per cent. Whether this was the result of more complex operations requiring greater supervision, or evidence of inflating management numbers to accommodate both more locals and more expatriates is difficult to judge, as the company ceased to release such figures in 1964. Yet taken together with evidence from other companies, the latter seems more likely. The number of Ghanaian managers increased rapidly between 1955 and 1957 (the years immediately before independence). Only after 1962 did large numbers of European managers leave UAC, and this followed the introduction of exchange controls and a high tax rate for expatriates in Ghana in 1961. In Nigeria, while the number of African managers increased faster than that of Europeans for most of the 1950s, despite some minor retrenchments of the latter late in the decade, the number of whites only began to decline rapidly in 1962 .

The size of management also increased at other companies, for example the BWA and AGC (Fry, 1976, p. 193; AGC, not dated; Stockwell, 2000). While Africans officially acceded to the same rank as the European they replaced, their actual duties were often more limited and partly taken over by the expatriate who was promoted to supervise his successor. In his study of management practices in Zambian copper mines in the 1960s Michael Burawoy refers to this as 'job fragmentation' (Burawoy, 1972, pp. 27-48).

In South Africa, a government investigation in 2006 uncovered a similar trend (Business Day, 2006c). A recent episode there shows that the issue is considered relevant even for very senior executives. Peter Moyo was forced to resign as the CEO of Alexander Forbes after a new private equity investor made the uncommon decision to appoint a (white) executive chairman, making it appear as if Moyo required a white supervisor (The Star, 2007d). These situations touch on two sensitive and inter-connected issues: the lack of trust in the ability of newcomers, and the underperformance or inability of newcomers to achieve the standards expected.

\subsubsection{Vicious Circle of Underperformance}


The attitudes of European managers are important for Africanization, because their assessment of the trustworthiness and ability of incumbents determined their prospects for promotion. These attitudes changed only very slowly. Frederic Seebohm, director of Barclays Bank DCO, commented in 1954 that 'it is very difficult for a European to assess the character and ability of an African', a comment similar to that of a US business magazine about African Americans in 1966: '[The Negro [sic] is a stranger who] emerges from another environment to come to work, and at the end of the day he returns to a world where few white men venture' (Laird, 2006, p. 227). By 1960, however, Seebohm's attitude showed a stronger class bias: 'The top-class Nigerians are good company and much more interesting than most of the British that one meets abroad.' Frederick Pedler (1965) of the UAC agreed:

The ministers you meet and the senior civil servants are people of impressive quality. This, I think, has been a comment offered by other people who have come back from Nigeria.

By the early 1960s, therefore, the social and cultural distance that was constantly being constructed within British companies was no longer upheld with regard to the emerging African elites. Political empowerment made African politicians and officials acceptable partners much earlier than African-Americans in the US. However, it was only later that the same occurred with attitudes towards senior African managers and businessmen. The British general manager of Dunlop in Nigeria, John Smith, was quoted in 1976 as saying that: 'At the top, Nigerian managers are quite outstanding', but he continued that 'the country lacked depth of management' (Oviogbodu, 1976).

These attitudes were obviously affected by the changing political landscape in West Africa. Colonial withdrawal gave Africans access to the top positions in the government and economy. While this opened up opportunities for the previously excluded, this was no social revolution. These positions were often taken by already existing elites, whose ability to break into top posts had been curtailed by the previous regime. The process of Africanization thus increased the stratification of society as Africans rose into leading positions, not only drawing level with, but also outranking Europeans for the first time in the twentieth century. The greater social proximity of elites opened up an avenue for cooperation (Granovetter, 1992, p. 65). This explains why expatriates changed their attitudes towards local elites, but continued to distance themselves from African employees and indeed the majority of the population. As the alignment of race and class was broken down, class gained increasing significance. In South Africa white businessmen have been criticized for preferring to partner with black South Africans who have money and political connections (UN, 2004).

This social and cultural distance towards African staff had a significant impact on opportunities for staff development and advancement. Managerial papers from the five companies studied indicate a vicious circle, based on the low expectations that British managers had of African staff performance, withdrawing responsibilities from new postings, and undermining them. The circle was fuelled further by the insecure position of African managers (see Figure 2) (see also Burawoy, 1972, pp. 52, 99). A similar dynamic has also been criticized in South Africa (The Star, 2007c). Management perceived it as risky when 
they were forced to extend their trust to virtual 'unknowns', because the potential opportunities for malfeasance increase with the level of trust placed in an individual (Granovetter, 1992, p. 62). Hence the lack of knowledge and understanding coupled with fear of incompetence or bad intentions created conditions which made it harder for new managers to perform well, and exacerbated an atmosphere of general insecurity and mistrust.

\section{INSERT FIGURE 2 ABOUT HERE}

Therefore, although overt discrimination in recruitment was removed during decolonization, it did not mean that Ghanaians or Nigerians had the same access to support networks and gatekeepers, who provided some informal training and preparation, screened potential applicants and determined promotion within the firm (Laird, 2006, pp. 6, 337). Without necessarily being aware of it, foreign companies had not really opened their internal professional networks for development and promotion to most African employees, as the significant gatekeepers in the firms still found it difficult to identify 'potential' or 'character' in recruits whom they perceived as fundamentally different from themselves. The result was a 'glass ceiling', albeit one that shifted upward over time.

Expatriate managers' lack of awareness of these issues was reflected in the language of debates over individuals' shortcomings, which often referred to problems of ability or 'character'. In 1945 Mr Pannel, one of Holt's managers, noted of the average Gold Coast recruit that 'he possesses the intelligence but too often lacks the integrity, understanding, initiative and sense of responsibility which make for the successful agent' (Milburn, 1977, p. 72). Although it was true that the supply of trained, efficient and enterprising managers was the weakest point of the Ghanaian economy (Lewis, 1953, p. 24), the opportunities for promotion were extremely limited for black Africans. One of UAC's managers in the Gold Coast, George Cole, characterized the company's problems with Africanization as follows:

For many years we have been doing our utmost to discover suitable African material for training to the higher posts of management. The results are disappointing to those who expect that fundamental changes in character can be brought about in a few years. Africans have risen to very responsible positions, but none of them has ever shown the capacity to challenge for the post of General Manager or anything approaching it. (Milburn, 1977, p. 77)

White managers did not realize that this was indicative of a failure to internally develop Africans with managerial potential. Despite differences among companies in the progress of Africanization, they shared an understanding about the limits of African advancement within the business community. At Barclays in Nigeria, ceilings had shifted upwards over time, but still existed in 1964: 
Though there are a number of good steady Africans in responsible positions, they nearly all seemed to me to lack the spark of real managerial ability; they might run small or medium sized branches adequately but would be unlikely ever to show the self-confidence and initiative needed to build up or expand a business. (Dyson, 1964)

Another problem was high levels of 'staff wastage', as many recruits left in order to take up better positions in terms of salary, professional development or opportunities for promotion. The West African countries only began to build a higher education system in the 1950s and had a relatively low share of population formally schooled - literacy rates for Ghana and Nigeria in the 1950s were between 10 and 20 per cent (Jolly, 1969, p. 104). South Africa, where spending on education was clearly skewed in favour of whites, has also experienced intense competition for suitable managers, like Ghana and Nigeria (Business Day, 2004b \& 2005a). With both the private and the public sectors competing for a limited pool of skilled labour, in conjunction with white emigration, staffing became a bottleneck threatening the successful implementation of these policies. At the same time, the logic of supply and demand meant that salaries for managers were rising, especially when compared to poorly trained and unskilled labour. Even as recruitment was strongly determined by the existing class structure in West Africa, it also served to reinforce stratification by lifting the educated elite towards expatriate standards of income.

\subsection{Managerial Control and Intra-African Competition}

The Africanization of management in Western companies in Ghana and Nigeria thus proceeded more slowly than African public opinion had anticipated, and by the 1960s firms became concerned about the limited results. Many were losing trained staff who saw better opportunities elsewhere, and pressure from trade unions and the media did not subside. In response, companies invested more in training and staff development, which offered wellproven mechanisms of indirect control through corporate socialisation, and eventually began to handpick recruits for fast tracking by experienced expatriates. This strategy created a stratum of employees, in whom business principals hoped to instil loyalty, distinct from the main workforce. Singling out capable individuals for further advancement created a twotier African labour force, and rapid promotion created rivalry among incumbents, among different generations, and among different ethnic groups. Empowering a majority population in poor countries proved to be much more divisive than Affirmative Action programmes in Western countries.

\subsubsection{Socialization and Control}

The issue of trust loomed large for companies seeking to Africanize their operations. Apart from the pervasive racist bias against Africans, British-based managers were concerned that 
they knew very little about the background of their Nigerian and Ghanaian recruits, which made them appear highly unpredictable and hard to control. Their expatriate staff in West Africa, white middle-class men with known educational credentials, had been trained on the job by trustworthy older people. Bonding was encouraged through joint accommodation in bachelors' messes or company housing. The companies controlled their movements by deciding on when and how they travelled homeward, with the ultimate sanction being the non-renewal of contract, although this was normally only imposed for serious misconduct (Jones, 1993).

This system of control and socialisation was not as easily established for Africans, although managerial recruits were hired from elite West African schools, and had often studied in the UK or the US. Corporate housing was, after an interval, made available to African managers and their membership of clubs was encouraged, but was not embraced enthusiastically by either African or expatriate staff (Milne, 1948; AGC, 1962; Stockwell, 2000, p. 175). While some efforts at socialisation were made, the treatment of European staff was changing at the same time, as careers were professionalized through structured training and more 'objective' assessment methods. The opportunities that were open to black staff for advancement were now circumscribed by what education they could afford.

While attaining the requisite educational standards was a challenge for recruits, acquiring tacit knowledge to perform well at one's job was equally necessary, and companies began to promote the development of social capital by establishing comprehensive training regimes for all staff, but particularly for new African recruits. UAC was amongst the first to recognize the need for an organized and comprehensive training establishment, which codified and standardized the knowledge that African recruits had to acquire in order to advance. In 1956, in an internal memorandum on 'ization', Andrew Knox (1976, p. 167), one of Unilever's directors, made it clear that the rise of local staff in managerial hierarchies had to be accompanied by thorough indoctrination into the corporate culture:

In the next stage which is to bring locally employed managers into the very highest positions in our business it becomes even more important that they should be "Unilever" men in the true sense and not merely good local operators [...] our task is not only, e.g. to Indianize our business in India but we must also Unileverize the Indians who have positions of authority in that business.

Knox, like others, believed they could imbue their employees with their corporate values and reap the benefits of their loyalty. As in most organizations, corporate culture in UAC and Unilever involved a tacit knowledge of how things were done, how situations were appropriately handled, when risks should be taken or avoided, when something should be sold at all costs, and which limits should not be exceeded. These norms have been conceptualized by Robert Simons (1995) as belief and boundary systems. The knowledge about desirable and undesirable practices is not comprehensive, all-encompassing, or stable, but it has the advantage of limiting monitoring costs to management and allowing subordinates greater freedom in taking decisions. The goal is to create an environment in which employees are treated as professionals, who have greater agency than staff in a bureaucratic control system (Fukuyama, 1995, p. 223). Although both approaches normally 
co-exist in companies, the professional paradigm is more likely to apply at management level. In this sense, the 'Unileverization' was a precondition to promotion, because it limited their 'otherness'. Often criticized as 'selling out one's culture' (Thomas, 2001, p. 8), as Figure 3 shows, these efforts did not pass unnoticed in African societies.

INSERT FIGURE 3 ABOUT HERE

The provision of training took different forms in different firms. UAC seems to have planned and publicized its efforts most comprehensively, opening six training schools in West Africa, the first in Nigeria in 1954. Barclays established a school teaching clerical skills in 1956, and gave some support to potential managerial staff preparing for their Institute of Bankers exams (Stockwell, 2000, pp. 142-3). The mining companies in Ghana used the Chamber of Mines to organize training schemes. The Consolidated African Selection Trust (CAST), a diamond mining company, had its own training programme. The Nigerian Institute of Management, founded by employers, provided not only training but also a forum for debate in conferences and their own magazine (Management in Nigeria, several years). Training was an issue on which all sides could agree: African employees, because it increased their educational credentials; European employers, because they wanted to develop the right 'character' and ability in their local staff. Using training as the main vehicle for the promotion had the advantage of being acceptable to both European superiors and African recruits, as African societies valued education very highly.

\subsubsection{Competition and Rivalry in the Empowerment of a Majority}

Africanization created winners and losers. Internal rivalries were the result, and Western companies would sometimes use them as excuses for their poor performance in promoting Africans (Fieldhouse, 1994, p. 380). Competition was particularly evident between different generations of senior African staff, and in Nigeria also among ethnic groups.

Newly recruited African trainees, in particular, faced potential disapproval from colleagues bypassed in the fast-tracking process. In his biography (1996) Joseph Appiah, a prominent Ghanaian politician, recounts an encounter in the army when he considered enlisting for officers' training in the 1930s. The African instructor there made it clear that he disapproved of plans to introduce black officers, arguing that if all black men were equal, none should have the privilege of crossing the colour bar. Eventually choosing a career in the UAC, Appiah (1996, pp. 108-11) found colleagues equally touchy about a new recruit earmarked for management fast-tracking, interpreting what he considered respectful behaviour 
towards his elders as snobbishness. The old guard, who had worked a lifetime in inherently racist foreign institutions, was bitter about the sudden change, which allowed young and inexperienced recruits to be rapidly promoted beyond the positions they could ever hope to reach.

In theory promotion rests on two principles: seniority and performance (Burawoy, 1972, pp. 41-2). In practice both principles tend to co-exist, inducing competition among employees to reach the next and better compensated rung on the corporate ladder. Beyond these consciously employed measures, social capital - whom you know and who supports you - is an important factor in gaining the trust and confidence of superiors (Laird, 2006, pp. 25-30, 53-59, 126-127). A senior executive manager at a British bank in Ghana, who had a long and highly successful career, described his experience thus (Interview, 2004a):

[...] there were one or a couple of local managers, black, Ghanaian managers [...] they lacked qualification, they didn't have what it took to be managers. They just came through the system and some of them were just there. You know, they had reached their peachiest point, [...] age was a factor because I was fairly young and I was leapfrogging these fairly old people who had been in the system for so long. [...] Because, don't forget, those people were promoted more on the length of time they spent in the bank as opposed to their own performance. So when I was performing and they were promoting me, of course that created a bit of a problem for them.[...] that was the time [the late 1960s and 1970s] when [...] barriers were being removed and people were being rewarded and promoted based on their performance.

This man had been mentored by an expatriate, sent to different bank branches within Ghana and to several other countries to broaden his experience, and eventually reached top executive level.

Another problematic area was education, especially language and literacy, which were important signifiers for the aspiring middle class in clerical and professional positions. In 1966 AGC's security officer (Beattie, 1966) reported on the discontent of the younger Ghanaian senior staff regarding 'the presence of a number of near illiterates in the senior staff. The more educated ones see this as a brake to management's wider consideration of their greater social aspirations.'

In Nigeria, ethnic rivalry was even more disruptive: the three major ethnicities had distinct social and professional profiles. The Yoruba, in the west, were the wealthiest group overall, with a long tradition of agricultural entrepreneurship, mainly in cocoa, and relatively high educational achievement. Due to their relatively strong economic base, they had a significant presence as professionals and clerks in business, but were far from dominant, partly due to better opportunities for self-employment. In contrast the eastern Igbo were from a relatively underdeveloped region, but had adopted Christianity more rapidly than other groups and, with it, Western-style education. Despite the lack of a strong economic base Igbos rapidly established themselves in the private and public sectors in typically whitecollar occupations like clerks, and benefited disproportionately from the removal of the colour bar (Falola \& Roberts, 1999, p. 526). As the East was relatively poor (especially before its petroleum reserves were exploited in the 1960s), Igbos had a significant diaspora 
presence in both the West and the North of the country. It was the Muslim Hausa-Fulani in the North, the preferred group of the British colonialists who consequently became politically dominant in the independent republic, who fell behind. Hausa society was effectively feudal, highly unequal, with little Western education and very low levels of literacy in English (literacy in Ajami, the Hausa script, was not significantly higher): around 5 per cent compared to 10-20 per cent in the other regions in 1952 (Royal Institute of International Affairs, 1960, p. 225).

Southerners, especially Igbos, consequently cornered civil service and many private sector jobs despite British preferences. Several pogroms against Igbos erupted in the North over political and economic grievances. Ethnic rivalry culminated in the Nigerian civil war of 19671970 (Nugent, 2004, pp. 89-98). In Nigeria ethnic divisions were so fundamental to political and commercial life that they frequently became the most important affiliation for individuals, even beyond class, and opportunities were distributed within the boundaries of ethnicity, or even village and ancestral associations.

Africanization was therefore controversial in ways that Europeans had not anticipated. It created opportunities that were distributed through existing networks, and excluded those who were too old, who had not been educated in the right schools, and who came from the 'wrong' social or ethnic group. These problems did not arise with the same severity in Affirmative Action in the United States.

What was similar to Affirmative Action was that West Africans were promoted first to socalled 'ghetto positions' in personnel (supervising other Africans), or highly visible posts such as public relations and 'political' directorships on local boards (Laird, 2006, pp. 221, 298; Thomas, 2001, p. 2). Positions of authority over Europeans went only late, if at all, to Africans, and the same held true for higher level technical and engineering jobs as well as those in central finance and accounting (UAC, 1959, p. 14). iv In South Africa too, as Southall (2006, p. 71) has observed, blacks have been appointed mainly to 'soft' positions in personnel, marketing and public relations, a trend that applies equally to the promotion of women. This underscores that a deep managerial commitment to Africanization came much later than the ostensible opening of higher level careers to Ghanaians and Nigerians. Only after the introduction of comprehensive skills development, fast-track and rotation programmes, and effective mentoring could there really be any claim that Africanization had become a strategic concern to business.

\section{Implications for Black Economic Empowerment in South Africa}

South African history is often viewed as distinct from the rest of colonial Africa (lliffe, 2007, pp. 273-287), but Mahmood Mamdani (1996) suggested that apartheid was a direct descendant of broader colonial traditions of indirect rule. The Union of South Africa gained dominion status in 1910 under white settler rule (English- as well as Afrikaans-speaking), making it effectively independent. The electoral success of the Afrikaner-dominated National Party (NP) in 1948 marked the imposition of segregationist policies, and the 
qualified franchise that Africans and Coloureds enjoyed in the Cape was soon revoked (Marks, 1999, p. 566, Nugent, 2004, pp. 131-136). South Africa's whites identified either as English or Afrikaans, while blacks belonged to many different groups such as Zulu or Xhosa. There were also coloureds (mixed-race people of white and black parentage) and Asians (mostly Indians and a few Chinese), who were generally treated better than black Africans. In 2001 black Africans made up almost 80 per cent of South Africa's populations with whites and coloureds each around 9 per cent (see Table II). Rates of economic participation and poverty still tell a clear story of the racial hierarchy that underpinned apartheid.

\section{TABLE II ABOUT HERE}

The African National Congress (ANC) was only one of many political groups, which struggled to find a viable form of opposition during the decades of apartheid. Together with other groups they signed the Freedom Charter of 1955, and the party remained committed to its vision of a multiracial South Africa until the end of the struggle. The 1960s, a period of significant economic growth (around 6 per cent annually), was a time of crisis for the opposition, when leading ANC members like Nelson Mandela were imprisoned. However, the apartheid system experienced a long-lasting and eventually terminal crisis in the 1970s and 1980s, as the economy declined, African trade unions became influential, and eventually, in the mid-1980s, even Afrikaner businessmen joined the intellectuals openly criticizing the government. In 1990, with the country wrecked by internal strife and police violence, President FW de Klerk revoked the ban on groups like the ANC and released Mandela and others from prison. Four years later the country experienced its first free general election, in which the ANC gained over 60 per cent of the vote (Nugent, 2004, pp. 294-318, 430-433). Subsequent disillusionment with the progress of poverty alleviation and business progress on voluntary empowerment led to the institution of more stringent guidelines and later legislation on Black Economic Empowerment in the late 1990s (BEE).

The stated intention of BEE, which began as a voluntary commitment by business to greater equity in employment and the transfer of ownership to previously disadvantaged individuals, was to assure proportional representation of blacks in the economy (Southall, 2006). Black Africans, coloureds and Asians are all defined as black for the purpose of the legislation, and recently South African-born Chinese have also qualified (African Business, 2008). Initially BEE focused almost exclusively on the transfer of equity to black empowerment consortia at the Johannesburg Stock Exchange. Empowerment requirements mostly targeted domestic white companies, and exceptions have been made for foreign companies (Business Day, 2005b; Mineweb, 2003a). However, many of the BEE-consortia collapsed due to over-leveraging following the Asian crisis of 1997-98 (Economist, 2001; Sunday Times, 2003a). Others, having benefited from official financial aid to further black ownership, sold out their stakes to white investors at a profit, which was heavily criticized in the media (Business Day, 2003a, 2004a and 2004c; Mineweb, 2003b). 
The issue of black employment became more important following the Employment Equity Act of 1998. The Act requires proportional representation of South Africa's population groups at all levels of employment and management in both the public and private sectors, and seeks to break the mould of 'white manager vs. black worker' (Daye, 2004, p. 66), or, as stated in Southall (2006, p. 82-3), 'the identification of race with economic function'. Employment Equity has been subsumed under the Broad-Based Black Economic Empowerment Act of 2004, which uses a Balanced Scorecard as an incentive to gain government contracts (see Table III).

\section{INSERT TABLE III ABOUT HERE}

Unfortunately, expectations of the efficacy and the power of BEE to fundamentally change the structure of business in South Africa are highly problematic. The US experience has shown that Affirmative Action programmes can open up entry into new sectors, but are relatively ineffective in aiding promotions or increasing diversity higher up the corporate ladder (Thomas \& Wetlaufer, 1997, p. 126; The Star, 2007b). The West African cases show similarly that internal dynamics need to change first for companies to promote relative outsiders to positions of real responsibility and trust. The reality for black managers in South Africa today appears to be that, although they receive significant legal backing from the government, within companies many are sidelined and not given responsible, challenging tasks (Hill \& Farkas, 2007; The Star, 2007c).

Even when the empowerment of a majority proves successful, the historical evidence from West African decolonization that it leads to a greater increase in inequality and stratification in a society than empowering a minority. Most African societies had fairly distinct class differences even during colonialism, and despite the view that apartheid oppressed all black South Africans, it oppressed some more than others (Crankshaw 1997, pp. 13-14).

Racial discrimination had some unintended side effects in South Africa (Crankshaw 1997, p. 114-122) and these prefigured many of the problems with BEE. In the 1950s, and even more the 1960s, many urban Africans advanced into semi-skilled manual, clerical and semiprofessional positions in the private and public sectors. Government policies of separate development actually boosted opportunities for African semi-professionals in sectors like health and education. Yet this went hand in hand with rising African unemployment overall, especially following recession in 1975 . Thus, while the racial wage gap narrowed in the 1970s, African incomes fell on average between 1960 and 1990. As a result inequality among black Africans today is almost as great as that between Africans and whites. Social class and residential patterns are becoming more relevant than race in determining inequality in today's South Africa, and this is an important factor in evaluating the discussions surrounding BEE.

Black advancement in South Africa showed a pattern similar to Waldinger's analysis (1996, p. 307), who argued, with respect to ethnic groups in New York, that once they had 
managed to break into occupational niches, they subsequently monopolized them for their own group, heightening inter-group rivalry and racial conflict. In South Africa middle-class blacks encountered little white resistance in routine, semi-professional, white-collar work in finance or commerce. However, union opposition in the skilled trades in construction, manufacturing and mining led to black advancement there being delayed by almost two decades (Crankshaw, 1997, pp. 116-7). As a result these positions are now held by a new black middle class, and are not automatically accessible to other black South Africans. There is rivalry among blacks, whites, coloureds and Asians, as well as between lower-class and middle-class blacks over access to the 'BEE-pie' (African Business, 2008, p. 29).

This new black middle class has been termed 'Black Diamonds' by market research institutes. The black share of the top 10 per cent of overall household incomes almost trebled between 1993 and 2000 (from 8 to 23 per cent) at the expense of whites, whose share declined from 79 to 63 per cent (Economist Intelligence Unit, 2006, p. 41). At the same time, structural unemployment in South Africa remains a pressing problem: in 2004 a shortage of 920,000 skilled workers was forecast, accompanied by a surplus of 11.5 million unskilled or semi-skilled workers (Jackson, 2004, p. 253). These structural inequalities have culminated in public criticism of the 'BEE-llionaires', black elites and crony capitalism (Southall, 2006, pp. 74-5, 78; Hill and Farkas, 2007, pp. 295, 305; Business Day, 2002, 2003a, 2006a; Economist, 2007; Mineweb, 2003a).

Thabo Mbeki's 1998 speech on the two South African nations, one black and one white, which he later changed to two economies, one poor and black, and one rich and white (Sunday Times, 2003b), is thus a problematic and outdated view of South Africa's social structure. While Mbeki argued for the need to right the 'wrongs of past injustices', Moeletsi Mbeki, the former president's brother, has publicly criticized the 'elite enrichment' that goes on as part of BEE (African Business, 2008, p. 29, also Terreblanche, 2002, pp. 391-400). However, comparisons with the current situation of African-Americans (Crankshaw, 1997, p. 121), Malaysia (Southall, 2006) and the experience of other African countries (Verhoef, 2004) are only rarely made, as there is a general assumption that South Africa faces unique conditions in addressing the legacy of apartheid.

However, I believe that the cases of Ghana and Nigeria presented earlier, as well as the experiences of other countries such as Zambia and Uganda, which have not been discussed here, show that this is a false assumption. Instead I would argue that South Africa's current experiment with BEE follows in a long tradition of postcolonial transition that is specific to African economies. The transition from colonial discrimination, however, does not fit the classic account of social capital and empowerment in Western countries. The key issue is of course that colonialism did not discriminate against minorities, but oppressed majority populations. The transition away from a race-based order increased social stratification substantially and suddenly, effectively creating a tournament to take over the leading positions in an economy that were successively abandoned by, or wrestled from, the previous elite group. This allows groups within the discriminated majority that hold advantages in terms of social class, age, education, ethnicity, wealth, geographical location etc. to take over powerful and lucrative positions in politics and business, similar to the 
competition for economic niches as described by Waldinger (1996) for minorities in New York.

This transition process takes place in emerging economies that suffer from problems such as having only a small, relatively undiversified economic base, dominated by invasive governments that tend to be captured by patronage networks and suffer from graft and corruption, and only imperfectly constrained by weak legal institutions and prone to suffer from economic and political shocks. Unsurprisingly, the experience in Ghana and Nigeria has been that the perceived inequities in the access to economic opportunities (either based on class or ethnicity, with the latter being particularly problematic) contributed to unsettling already fragile political systems, especially when accompanied by economic shocks. What this may mean for the future of the South African economy, particularly in the light of the present Financial Crisis, is hard to say, also because research on postcolonial transitions in Africa has more frequently focused on culture rather than on business and the economy. What emerges from historical research on postcolonial Africa is that transitions were rarely managed without considerable conflict and the emergence of highly politicised redistributional regimes (Chabal \& Daloz, 1997). Moreover, poorer African economies struggle with the divisive effects of empowerment programmes such as Africanisation and $\mathrm{BEE}$, and the ensuing competition to gain access to state resources.

\section{Conclusion}

As my West African case studies show, foreign-owned business in Ghana and Nigeria at first tended to manage demands for Africanization by outwardly complying, but without developing an internal commitment to give Ghanaians and Nigerians greater responsibility. As a result, window-dressing occurred in highly visible positions, and managerial numbers increased relative to the size of the business, as jobs were fragmented to ensure continued supervision by expatriates. The performance of African managers was poor because internal development mechanisms continued to bypass them. The internal dynamics in these companies were characterized by considerable social and cultural distance between Europeans and Africans. As this distance decreased, especially in elite circles, it became easier to promote Africans in European-owned companies. However, the result was an increase in inter-generational rivalry among different groups of Africans. In Ghana, conflict was mostly class-based, whereas in Nigeria ethnicity was much more problematic. Eventually it was comprehensive training, internal development, mentoring, job rotation and similar measures (many of which feature in the social capital and empowerment literature), which were acceptable to both Europeans and Africans, and that created credibility and respect for African managers. Companies with a long tradition of comprehensive training in Africa have been able to build a good managerial cadre even if this process has been fraught with difficulty. Others still find it difficult to recruit competent staff due to severe skills shortages and out-migration of well-educated professionals. 
However, as the cases of Ghana and Nigeria show, even when the process of majority empowerment has achieved important success it has also been hugely disruptive, both socially and politically. There is a large gap between the aspiration of making all positions in the public and private sectors available to black Africans on the basis of merit, and the reality that access depends heavily on class, ethnicity, gender ${ }^{v}$ and place of residence (in part due to pervasive poverty and poor educational provision). This gap between aspiration and reality has been one of the causes of instability in postcolonial African societies.

This paper has compared two historical cases with the situation in present-day Africa, and highlighted broad similarities in the process and the outcome of realigning business to a changed social order. This shows that almost all sub-Saharan African economies undergo similar postcolonial transitions by virtue of having to overcome a race-based social order (colonialism or apartheid). The same is true for some Asian countries, such as Malaysia. By employing concepts from social capital theory it becomes clear that this process differs from the empowerment experience of Western countries. Due to the scarcity of easily comparable data on African economies, there has been little to no research on the continent (Hoskisson et al., 2000, Wright et al., 2005). However, by widening the range of acceptable data and approaches, new concepts and categories can be developed that may serve as basis for future research. As this paper has shown, the process of postcolonial transition has occurred in many African economies, and further historical research on the nature and impact of these transitions can add to our understanding of the institutional environment in emerging economies in Africa and elsewhere. 


\section{Illustrations \& Tables}

Table I: Changing composition of UAC management in West Africa, 1949-1964

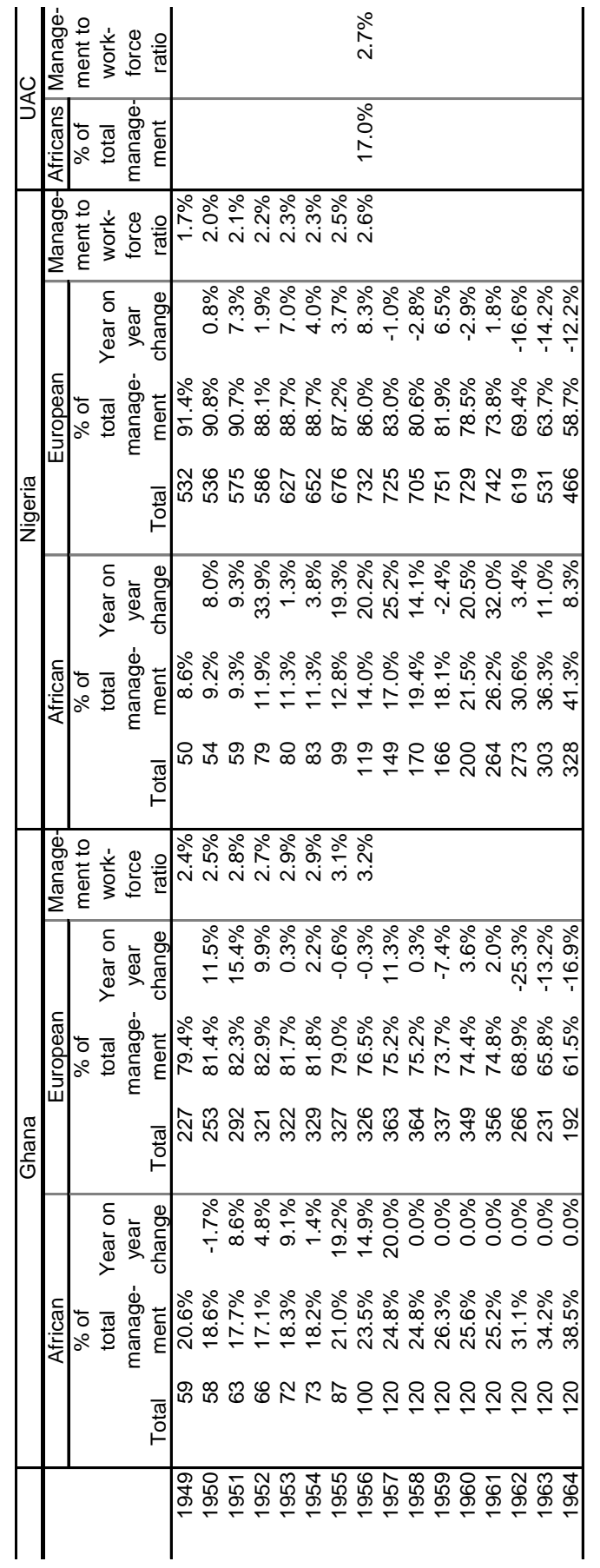

Source: UAC (several years). 
Table II: South African Labour Statistics

\begin{tabular}{rcccc}
\hline & African & Asian & Coloured & White \\
\hline Population 2001 & 79 & 2.5 & 8.9 & 9.6 \\
All industry staff 1999 & 53.9 & 4.4 & 10.2 & 31.5 \\
Management 1999 & 6.9 & 4.3 & 4.4 & 84.4 \\
\hline Unemployment rate 1995 & 37.8 & 13.8 & 22.8 & 5.8 \\
Unemployment rate 2005 & 44.8 & 21.1 & 30.1 & 7.9 \\
Poverty rate 2000 & 45.9 & 1.8 & 14.9 & 0.6 \\
\hline
\end{tabular}

Source: Adam (2000), pp. 186-187; Werker (2007), p. 13

Table III: The Black Economic Empowerment scorecard

\begin{tabular}{llr}
\hline Core component of BEE & Indicators & Weighting (\%) \\
\hline Equity Ownership & Black share of economic benefits & 20 \\
Management & Proportion of black people in executive management & 10 \\
Employment equity & Weighted employment equity analysis & 10 \\
Skills development & Skills development expenditure as a proportion of payroll & 20 \\
Preferential & Procurement from black-owned and black-empowered & \\
procurement & enterprises as a proportion of total procurement budget & 20 \\
Enterprise development & Investment in black-owned and black-empowered enterprises & \\
Residual & as a proportion of total assets & 10 \\
& To be determined by sector/enterprises & 10 \\
\hline
\end{tabular}

Source: Department of Trade and Industry (South Africa), (n.d.), pp. 21-24. 
Figure 1: Percentage of Africans in managerial positions in several firms

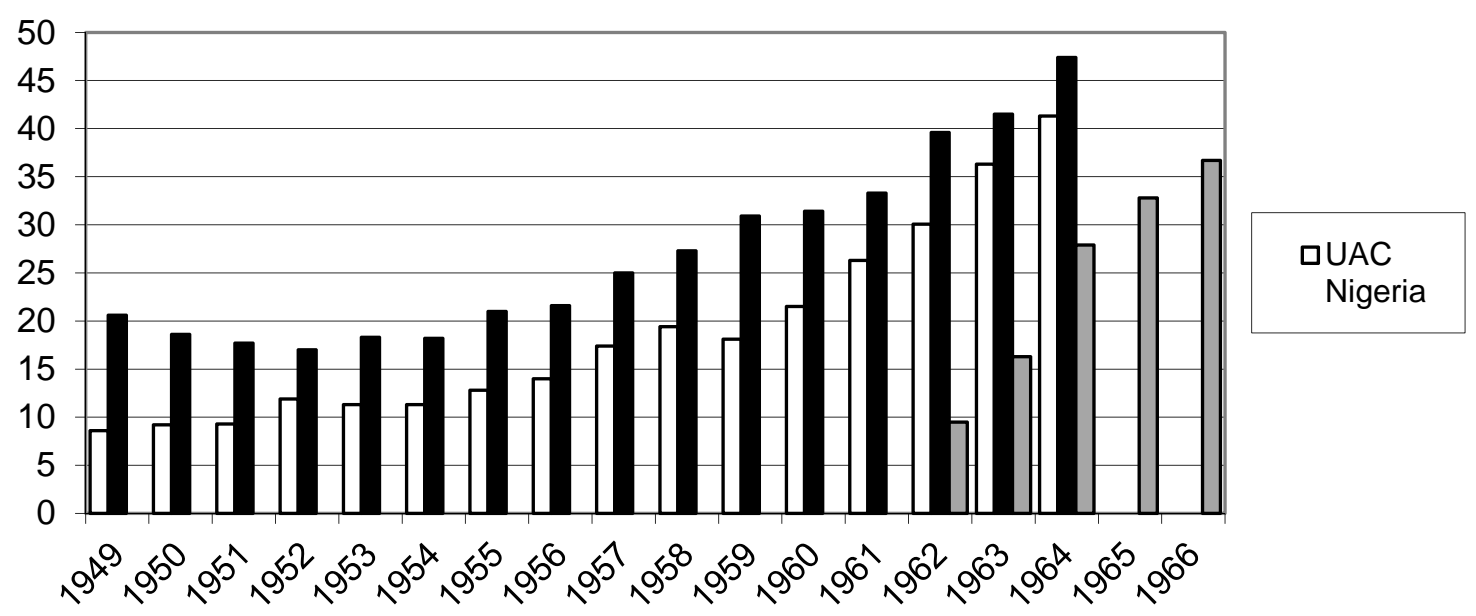

Source: UAC (several years); AGC $(1961,1963,1966)$.

Figure 2: Vicious circle of low African performance

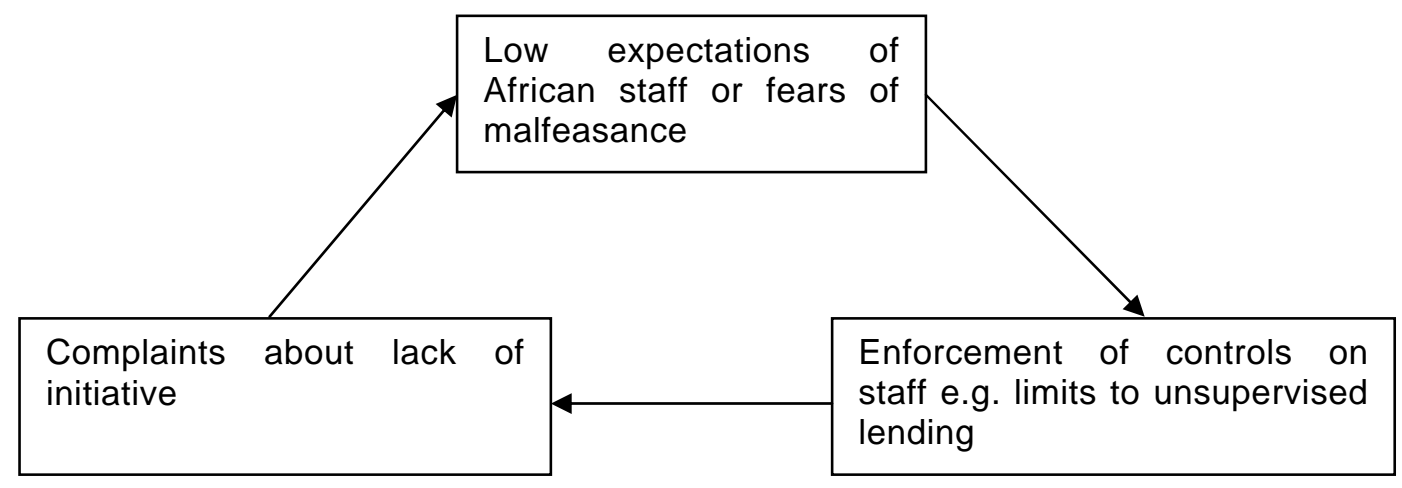

Figure 3: Nigerian caricature of shifting identities in the 1970s 


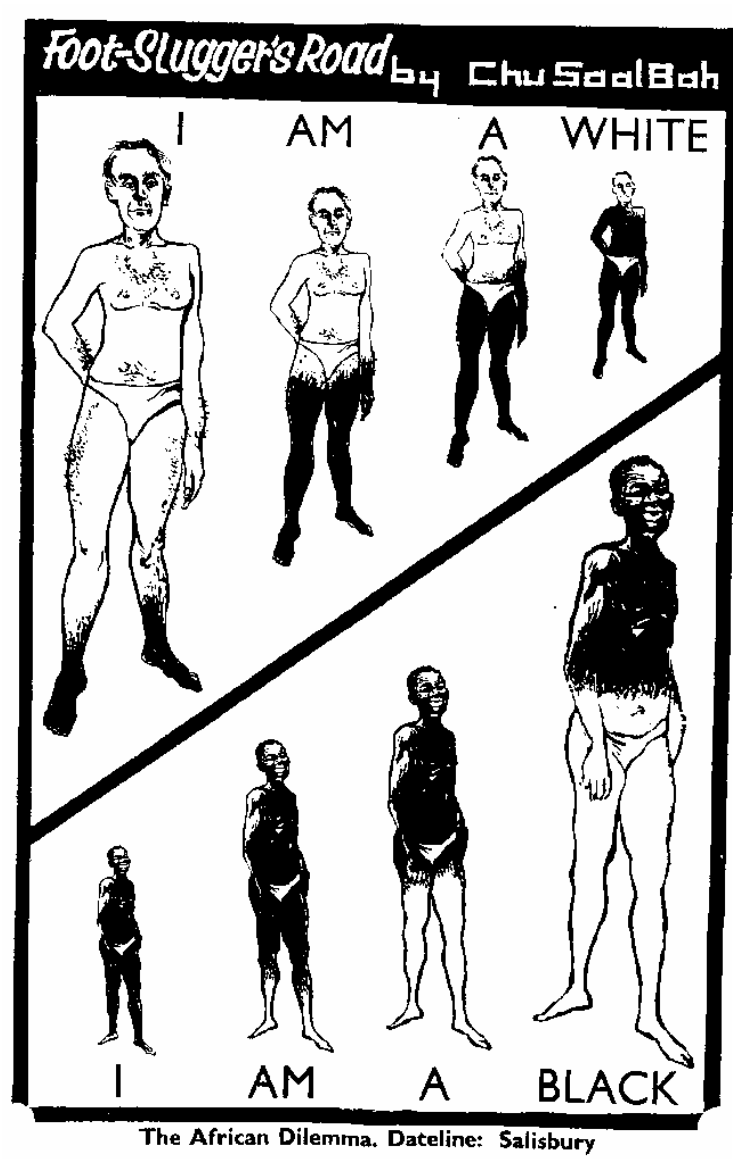

Source: Afriscope (Nigeria) (1971), 10. 


\section{Bibliography}

African Business (2008). 'Chinese are now black - official'. August/September, 28-29.

Afriscope (Nigeria) (1971). 'The African Dilemma'. 1,3.

Ake, C. (1981). 'Presidential Address to the 1981 Conference of the Nigerian Political Science Association', West Africa, 25 May.

--- (2000). The Colour of Business: Managing Diversity in South Africa.Basel: P. Schlettwein Publishing.

Alderfer, C. P., \& Smith, K. K. (1982). 'Studying Intergroup Relations Embedded in Organizations'. Administrative Science Quarterly, 27,1, 35-65.

Ashanti Goldfields Corporation (1961) 'Ag. General Mines Manager to Secretary', 12 September, Guildhall Library London [hereafter GLL] Ms 24,663, v. 1.

--- (1962). 'Minutes of PR Committee'. 9 November, GLL Ms 24,663, v. 3.

--- (1963). 'Minutes of Heads of Departments meeting', 15 February, GLL Ms 24,663, v. 4.

--- (1966). 'Minutes of Heads of Departments', 22 April, GLL Ms 14,171, v. 164.

--- (not dated). 'Photographs'. GLL Ms 24,661.

Appiah, J. (1996). Joe Appiah: The Autobiography of an African Patriot. Accra: Asempa.

Austin, G., \& Uche, C. U. (2007). Collusion and Competition in Colonial Economies: Banking in British West Africa, 1916-1960. Business History Review, 81(1), 1-26.

Barclays Bank DCO (1960). 'Memorandum 'CAST' to General Manager'.30 June, BGA $80 / 3580$.

Bayart, J.-F. (1993). The State in Africa: The Politics of the Belly. London: Longman.

Beattie, J. (1966). 'Intelligence Report No. 4 of 1966'. 18 July, GLL Ms 14,171, v. 165.

Biersteker, T. J. (1987). Multinationals, the State, and the Control of the Nigerian Economy. Princeton, NJ: Princeton University Press.

Biz-Community (2008). 'South Africa: Is There a Viable Black Middle Class?'. 15 January.

Boreham, F. A. (1961). 'Letter to Julian Crossley'. 3 January, BGA 80/3580.

Burawoy, M. (1972). The Colour of Class on the Copper Mines: From African Advancement to Zambianization., Manchester: Manchester University Press.

Business Day (2008a). 'Skills before BEE for Country's Companies'. 24 April.

--- (2007a). 'Ownership ranks low in Empowerment-Report'. 25 April.

--- (2007b). 'Brush the Cobwebs off original Equity Intentions'. 12 September.

--- (2006a). 'Turning an Ear to BEE Alarm Bells'. 12 June.

--- (2006b). 'State to Investigate Slow Progress in BEE'. 23 August. 
--- (2005a). 'Retaining Black Staff about more than Pay'. 7 October.

--- (2005b) 'Relief for Multinationals in New Black Economic Empowerment Code'. 20 December.

--- (2004a). 'Behind the Smoke And Mirror of Black Economic Empowerment'. 21 June.

--- (2004b). 'Poaching Employees from Rivals has its pitfalls'. 17 August.

--- (2004c) 'With Empowerment Must Come Accountability'. 29 October.

--- (2003a). 'Black Elite Needs to be Accountable'. 15 August.

--- (2002). 'Juggling Needs of Capital and Social Upliftment'. 22 August.

Butler, L. J. (2007). Copper Empire: Mining and the Colonial State in Northern Rhodesia, c. 1930-64. Houndmills: Palgrave Macmillan.

Chabal, P., \& Daloz, J.-P. (1999). Africa Works: Disorder as Political Instrument. Oxford: James Currey.

Coker, D. D. A. (1976). 'Letter', Trading in West Africa, ed. by Peter N Davies. London: Croom Helm, 157-172.

Crankshaw, O. (1997). Race, Class, and the Changing Division of Labour under Apartheid. London \& New York: Routledge.

Daye, R. (2004) 'Responsible Change in the Wake of Apartheid: The Case of Toyota South Africa', in Frederick Bird, Emmanuel Raufflet and Joseph Smucker (eds), International Business and the Dilemmas of Development. London: Palgrave Macmillan.

Decker, S. (2005) 'Decolonising Barclays Bank DCO? Corporate Africanisation in Nigeria, 1945-69', Journal of Imperial and Commonwealth History. 33,3, 419-440.

--- (2006) 'Building up Goodwill: British Business and Economic Development in Ghana and Nigeria, 1945 - 1977'. University of Liverpool: PhD thesis.

Department of Trade and Industry (South Africa), (n.d.). South Africa's Economic Transformation: A Strategy for Broad-Based Black Economic Empowerment [accessed online 15 September 2008, http://www.dti.gov.za/bee/bee.htm].

Dyson, R. G. (1964). 'Visit to Nigeria'. January/February, p. 3, BGA 80/4641.

Economist (2007). 'Just lighten up a little - South Africa'. 3 March.

--- (2001). 'Inequality changes colour'. 24 February.

Economist Intelligence Unit (2006). Country Profile 2006: South Africa [online resource]

Falola, T., \& Roberts, A. D. (1999). West Africa. In J. M. Brown and W. R. Louis (Eds.), The Oxford History of the British Empire: 515-529. Oxford and New York: Oxford University Press.

Fieldhouse, D. K. (1994). Merchant Capital and Economic Decolonisation: The United Africa Company 1929-1987. Oxford: Clarendon. 
Fry, R. 1976. Bankers in West Africa: The History of the British Bank of West Africa. London: Hutchinson Benham.

Fukuyama, F. (1995). Trust: The Social Virtues and the Creation of Prosperity. New York a.o.: The Free Press.

Granovetter, M. (1992). 'Economic Action and Social Structure: The Problem of Embeddedness', inM. Granovetter and R. Swedberg (Eds), The Sociology of Economic Life. Boulder, CO, : Westview, 53-84.

Gocking, R. S. (2005). The History of Ghana. Westport: Greenwood Press.

Hill, L. and Farkas, M. (2007). 'A Gentler Capitalism: Black Business Leadership in the New South Africa', in V Kasturi Rangan, John A Quelch, Gustavo Herrero, and Brokke Barton (Eds),Business Solutions for the Global Poor: Creating Social and Economic Value. San Francisco, CA: John Wiley\& Sons.

Hopkins, A. G. (1973). An Economic History of West Africa. Harlow: Longmans.

Hoskisson, R. E., et al. (2000). 'Strategy in Emerging Economies', Academy of Management Journal. 43,3, 249-267.

Iheduru, O. C. 2004. Black Economic Power and Nation-Building in Post-Apartheid South Africa. Journal of Modern African Studies, 42(1): 1-30.

Iliffe, J. 2007. Africans. Cambridge: Cambridge University Press.

Interview (2004a). Senior executive manager of Barclays Bank of Ghana, 6 July.

Jackson, T. (2004). Management and Change in Africa: A Cross-Cultural Perspective. London and New York: Routledge.

Jolly, R. (1969). Planning Education for African Development: Economic and Manpower Perspectives. Nairobi: East African Publishing House.

Jones, G. (1993). British Multinational Banking, 1830-1990. New York: Oxford University Press.

Knox, A. M. (1976). Coming Clean: A Postscript after Retirement from Unilever. London: Heinemann.

Laird, P. W. (2006). Pull: Networking and Success since Benjamin Franklin. Cambridge, MA: Harvard University Press.

Lewis, W. A. (1953). Report on the Industrialisation and the Gold Coast. Accra: Government Printer.

Mager, A. K. (2008). Apartheid and business: Competition, monopoly and the growth of the malted beer industry in South Africa. Business History, 50(3), 272 - 290.

Mamdani, M. (1996). Citizen and Subject: Contemporary Africa and the Legacy of Late Colonialism. New Haven: Princeton University Press.

Marks, S. (1999). Southern Africa. In J. M. Brown and W. R. Louis (Eds.), The Oxford History of the British Empire: 545-573. Oxford and New York: Oxford University Press.

Mda, Zakes (2002), The Heart of Redness. New York : Farrar, Straus and Giroux. 
Milburn, J. F. (1977). British Business and Ghanaian Independence. Hanover, NH: University Press of New England.

Milne, W. W. (1946). 'General Report on a Visit to West Africa'. 9 June, p. 6: entry for Kumasi, 16 May, BGA 38/906.

Mineweb (2003a). 'Black Empowerment Farce Deepens'. 25 August.

--- (2003b). 'Broad-based Empowerment is a Must'. 21 October.

Nicolson, I. F. (1969). The Administration of Nigeria 1900-60: Men, Methods, and Myths.

Oxford: Clarendon Press.

Nugent, P. 2004. Africa since Independence: A Comparative History. Basingstoke: Palgrave Macmillan.

Olusanya, G. O. (1975). The Evolution of the Nigerian Civil Service, 1861-1960: The Problem of Nigerianization. Yaba, Lagos and Nigeria: University of Lagos.

Orizu, N. (1961). 'Hansard, Senate', 1961 -1962 session, 30 March, col. 315, cited in: Bretton, H. L. (1992). Power and Stability in Nigeria: the Politics of Decolonisation. New York: Praeger, p. 191, FN 12.

Oviogbodu, G. (1976). 'At the top, Nigerian managers are quite outstanding. Interview with John Addison Smith'. Management in Nigeria, November, pp. 8-9.

Pedler, F. J. (1965). 'Report to Directors' Conference'. Unilever Archives [hereafter UA], UNI/SC with Tropical Africa Committee, 10 December.

Peng, M. (2003). 'Institutional Transitions and Strategic Choices', Academy of Management Review, 28,2, 275-296.

Royal Institute of International Affairs (1960). Nigeria: The Political and Economic Background. London, Ibadan, New York: Oxford University Press.

Seebohm, F. (1954). Diaries, 'Ghana'. 31 January to 9 February, BGA 277/1.

--- (1960). Diaries, 'Visit to Nigeria'. 29 January to 16 February, entry for 29 and 30 January, BGA 277/3.

Simons, R. (1995). 'Control in an Age of Empowerment'. Harvard Business Review, MarchApril, 80-88.

Sklar, R. L. (1975). Corporate Power in an African State: The Political Impact of Multinational Mining Companies in Zambia. Berkeley and Los Angeles: University of California Press.

Southall, R. (2006). 'Ten Propositions about Black Economic Empowerment in South Africa'. Review of African Political Economy, 111, 67-84.

The Star (South Africa) (2007a). 'Findings contradict earlier studies'. 3 August.

--- (2007b). 'Busa slams snail's pace of corporate BEE'. 23 August.

--- (2007c). 'Throw us into the deep end, challenges Manyi'. 10 October. 
--- (2007d). 'The big guns bumble on BEE: Unpleasant Alexander Forbes episode contains some crucial lessons for black professionals'. 5 December.

Thunderbird International Business Review (2009). 'Special Issue: Sub-Saharan Africa at a Key Inflection Point'. July/August, 317-405.

Stockwell, S. E. (2000). The Business of Decolonization: British Business Strategies in the Gold Coast. Oxford: Clarendon.

Sunday Times (2003a). 'Black Empowerment's Lone Heretic'. 6 April.

--- (2003b). 'A Tale of Two Nations'. 26 October.

Terreblanche, S. 2002. A History of Inequality in South Africa, 1652-2002. Pietermaritzburg: University of Natal Press.

Thomas, D. A. (2001). 'The Truth about Mentoring Minorities: Race Matters'. Harvard Business Review, April, 1-12.

--- \& Wetlaufer, S. (1997). 'A Question of Color: A Debate on Race in the U.S. Workplace'. Harvard Business Review, September-October, 118-132.

Tignor, R. L. 1998. Capitalism and Nationalism at the End of Empire: State and Business in Decolonizing Egypt, Nigeria, and Kenya, 1945-1963. Princeton, N.J.: Princeton University Press.

United Africa Company (several years). Statistical and Economic Review. London: UAC.

UN (Integrated Regional Information Networks) (2004). 'Anger over enrichment of Black Elite', 11 November.

Verhoef, G. (2004). 'Economic Empowerment and Performance: Strategies towards Indigenisation/Black Economic Empowerment and the Performance of such Enterprises in Nigeria and South Africa, since the early 1970's to 2002'.Journal of Contemporary History (South Africa), 29,2, 92-118.

Waldinger, R. (1996). Still the Promised City? African-Americans and New Immigrants in Post-Industrial New York. Cambridge, MA; London, England: Harvard University Press.

Wathen, J. (1961a). 'Letter to B. F. Macdona'. 15 April, BGA 11/2390.

--- (1961b). 'Letter to G. N. M. Law'. 29 September, BGA 80/3580.

--- (1964). 'Letter to J. Crossley'. 20 January, BGA 80/3580.

--- (not dated). 'Reminiscences'. BGA 1189/1.

Werker, E. (2007).' Foreign Direct Investment and South Africa'. Harvard Business School Case, 9-707-019.

Wright, M. et al. (2005).'Strategy Research in Emerging Economies: Challenging the Conventional Wisdom', Journal of Management Studies, 42,1, 1-33. 
This research was partly supported by the Arts and Humanities Research Council (UK), the University of Liverpool Research Fund and the Economic History Society travel grants. I gratefully acknowledge the helpful comments by Rory Miller, John Wilson, and the anonymous reviewers.

${ }^{\mathrm{i}}$ The only two sub-Saharan African countries not colonised were Liberia and Ethiopia.

${ }^{\text {ii }}$ Similar processes have occurred in Zambia, and there have been a number of interesting studies (Burawoy, 1972; Butler, 2007; Sklar, 1975).

iii No detailed records remain for John Holt.

${ }^{\text {iv }}$ At the UAC 25 percent of African managers were classified as trading, 13 percent as specialist/technical, and 30 percent as administrative in January 1959. The rest presumably had no specialisation.

${ }^{v}$ Although gender has been ignored in this analysis, it is another important factor. There are noticeable differences in the way gender was discussed in the 1960s and the 1990s, and hence it somewhat detracts from the argument made about race. There was a significant gender debate in South Africa in 2006/7 over whether (white) women should continue to benefit from BEE. As gender was not an issue that management was sensitive to for most of the 1950s and 1960s (the first female managers appeared in West Africa in the 1970s), it has not been as controversial in the West African case and was thus excluded from analysis. 